\title{
Extracellular-regulated kinase and p38 mitogen-activated protein kinases are involved in the antiapoptotic action of $17 \beta$-estradiol in skeletal muscle cells
}

\author{
Ana Carolina Ronda, Andrea Vasconsuelo and Ricardo Boland \\ Departamento de Biología, Bioquímica y Farmacia, Universidad Nacional del Sur, San Juan 670, Bahía Blanca 8000, Argentina \\ (Correspondence should be addressed to R Boland; Email: rboland@criba.edu.ar)
}

\begin{abstract}
$17 \beta$-Estradiol $\left(\mathrm{E}_{2}\right)$ stimulates the mitogen-activated protein kinases (MAPKs) in various cellular types. We have shown that the hormone activates extracellular-regulated kinase (ERK) and p38 MAPK in skeletal muscle cells. However, the functions of MAPK modulation by the estrogen in muscle cells have not been studied yet. We have recently reported antiapoptotic actions of $\mathrm{E}_{2}$ in $\mathrm{C} 2 \mathrm{C} 12$ cells. Here, the role of MAPKs mediating the hormone effect in muscle cells was investigated. The results showed that cells exposed to $0.5 \mathrm{mM}$ hydrogen peroxide $\left(\mathrm{H}_{2} \mathrm{O}_{2}\right)$ presented cytoskeleton disorganization, mitochondrial redistribution, and picnotic/ fragmented nuclei. Pretreatment with $10^{-8} \mathrm{M} \mathrm{E}_{2}$ prevented these morphological apoptotic characteristics, except in the presence of ERK or p38 MAPK inhibitors, U0126 and SB203580 respectively. Mitochondrial membrane integrity was also studied. Preincubation of cultures with $10^{-8} \mathrm{M} \mathrm{E}_{2}$
\end{abstract}

abrogated $\mathrm{H}_{2} \mathrm{O}_{2}$ effects such as Janus Green oxidation, presence of cytochrome $c$ oxidase activity in the cytoplasm, and SMAC/DIABLO release from mitochondria. When MAPKs were inhibited, the hormone could not prevent mitochondrial membrane damage exerted by oxidative stress. Blocking experiments with small interfering RNAs confirmed that both ERK and p38 MAPKs mediate the antiapoptotic effects of the hormone at the mitochondrial level. Further, some of the molecular mechanisms involved were also investigated. Thus, $\mathrm{E}_{2}$ was able to induce AKT (Ser473) and BAD (Ser112) phosphorylation in C2C12 cells in the absence or in the presence of $\mathrm{H}_{2} \mathrm{O}_{2}$ but not when the cultures were incubated with $\mathrm{H}_{2} \mathrm{O}_{2}$ and MAPK inhibitors. Altogether, these results show that $\mathrm{E}_{2}$ exerts a survival action in skeletal muscle cells involving ERK and p38 MAPK activation.

Journal of Endocrinology (2010) 206, 235-246

\section{Introduction}

Skeletal muscle mass decreases with age by reduction in fiber number and atrophy of the remaining muscle fibers. Various mechanisms have been postulated mediating these events (Dean et al. 1997, Chevion et al. 2000) including apoptosis (Dirks \& Leeuwenburgh 2002). Pathophysiological and certain physiological conditions demonstrate that apoptosis plays a key role in skeletal muscle cell loss (Sandri et al. 1995). There is evidence demonstrating that sarcopenia involves an apoptotic mechanism and suggests that aged skeletal muscle is characterized by an increased rate of cell death by apoptosis (Dirks \& Leeuwenburgh 2002).

Diverse stimuli trigger apoptosis by activating intrinsic or extrinsic pathways, which converge in the activation of caspases (Steller 1995). The hallmark of the intrinsic pathway is mitochondrial involvement (Jiang \& Wang 2000, Saleh et al. 2000). Cytochrome $c$ and SMAC/DIABLO play key roles ensuring the activation of the apoptotic cascade (reviewed by Jiang \& Wang (2004)). These proteins are localized in the mitochondrial intermembrane space and are loosely attached to the surface of the inner membrane of the organelle. In response to a variety of apoptosis-inducing agents, they are released from mitochondria to the cytosol (Liu et al. 1996, Reed 1997). Cytochrome $c$ triggers the apoptosome formation (Riedl \& Salvesen 2007) and the antagonist function of SMAC/DIABLO on the inhibitor of apoptosis protein (Hu \& Yang 2003). It has been shown that SMAC/DIABLO is an important regulator of hydrogen peroxide $\left(\mathrm{H}_{2} \mathrm{O}_{2}\right)$-induced apoptosis in $\mathrm{C} 2 \mathrm{C} 12$ skeletal muscle cells, activating caspase-3 and -9 (Jiang et al. 2005). The mitochondrial pathway is regulated by BCL2 proteins, which display either antiapoptotic (BCL2 or BCL-XL (BCL2L1)) or proapoptotic function (BAD, BAX or BID). The activity of different proapoptotic BCL2 family members is controlled by distinct posttranslational modifications. $\mathrm{BAD}$, a proapoptotic protein, is inactivated by phosphorylation, and then is sequestered in the cytosol by the 14-3-3 regulatory protein. Apoptotic stimuli lead to its dephosphorylation and dissociation from 14-3-3 regulatory protein, allowing BAD to form a complex at the mitochondrial level resulting in cellular death (Yang et al. 1995, Zha et al. 1996, Lizcano et al. 2000). 
It is known that estrogens exert actions in skeletal muscle. Degenerative pathologies of the muscle mass, like sarcopenia, observed in menopausic women are due to decreased levels of estrogens (Dionne et al. 2000). Accordingly, hormone replacement therapy promotes the growth and recovery of the muscular tissue (Dionne et al. 2000). In agreement with these observations, skeletal muscle recovers its normal physiology after administration of $17 \beta$-estradiol $\left(E_{2}\right)$ in ovariectomized rodents (Warren et al. 1996, Kadi et al. 2002). Likewise, other studies suggest that this hormone is important in the improvement of the muscular mass in cases of atrophy (McClung et al. 2006, Sitnick et al. 2006), and modulates the activity of myosin, a key protein in muscle contraction (Moran et al. 2007). Importantly, data show that estrogen-based treatment in postmenopausal women beneficially affects muscle strength (Greising et al. 2009). Of relevance to this work, it has been reported that $\mathrm{E}_{2}$ protects skeletal muscle against oxidative damage (Persky et al. 2000, Tiidus 2005), and we have recently demonstrated that the steroid hormone exerts antiapoptotic effects in the $\mathrm{C} 2 \mathrm{C} 12$ muscle cell line upon exposure to $\mathrm{H}_{2} \mathrm{O}_{2}$ or etoposide involving the phosphatidylinositol 3-kinase (PI3K)/AKT/ BAD pathway (Vasconsuelo et al. 2008). Also, the antiapoptotic action of the steroid hormone has been reported in other tissues. For example, estrogen treatment following severe burn injury reduces brain inflammation and apoptotic signaling, increasing the levels of phospho-AKT, inhibition of caspase- 3 activation, and PARP cleavage (Gatson et al. 2009). Razandi et al. (2000) reported a rapid mechanism by which $\mathrm{E}_{2}$ prevents chemotherapy or radiation-induced apoptosis of breast cancer, probably mediated through the plasma membrane estrogen receptor and regulating BCL2 family members. Nevertheless, the molecular mechanisms by which the hormone exerts antiapoptotic action in skeletal muscle cells are still poorly understood.

The mitogen-activated protein kinases (MAPKs) are an evolutionary conserved family of intracellular signaling molecules which have three major members: extracellular signal-regulated kinase (ERK1/2), p38 (p38 $\alpha$, p38 $\beta$, p38 $\gamma$, and $\mathrm{p} 38 \delta$ ) MAPK, and c-Jun N-terminal kinase, also known as stress-activated protein kinases (JNK1, JNK2, and JNK3). All MAPKs are activated by phosphorylation via different upstream MAPK kinases (MKKs or MEKs), and MKKs are activated by MAPK kinase kinases (MEKKs). While ERK is preferentially stimulated in response to growth factors, and regulates cell proliferation and differentiation, both JNK and p38 signaling pathways are responsive to stress stimuli, such as cytokines, u.v. irradiation, heat and osmotic shock, and are involved in cell differentiation and apoptosis (Pearson et al. 2001). Recently, in the skeletal muscle cell line C2C12, we found that $E_{2}$ is able to induce a fast activation of ERK and p38 MAPK leading to the phosphorylation of Creb and Elk1 transcriptions factors (Ronda et al. 2007) through estrogen receptors, protein kinase $\mathrm{C}$ and SRC (A Ronda, C Buitrago \& R Boland, unpublished observations).
This effect of the steroid on MAPKs has been observed in other cellular types (Razandi et al. 2000, Manolagas \& Kousteni 2001, Acconcia \& Marino 2003). It has been demonstrated that MAPK family members can regulate apoptosis in different tissues. Specifically, activation of ERKs is mostly related to cell survival in response to several mitogenic factors, whereas the p38 MAPK pathway is required for apoptosis or survival depending on cell types and conditions (Wada \& Penninger 2004). Of relevance, Alexaki et al. (2006) have demonstrated that neuroprotective effects of $E_{2}$ involve the activation of ERK and p38 MAPKs. However, the participation of ERK and p38 MAPKs in the antiapoptotic action of $E_{2}$ on skeletal muscle cells has not been studied yet.

Given that $E_{2}$ exerts survival actions against apoptosis (Vasconsuelo et al. 2008) and is able to stimulate MAPKs in C2C12 cells (Ronda et al. 2007), we hypothesize that both mechanisms are linked. Hence, the objective of the present work was to investigate the role of ERK and p38 MAPK in mediating protective effects in skeletal muscle cells. To this end, we used the murine skeletal muscle cell line $\mathrm{C} 2 \mathrm{C} 12$ as an experimental model and $\mathrm{H}_{2} \mathrm{O}_{2}$ as inducer of apoptosis. To study the involvement of MAPKs in the antiapoptotic action of the estrogen, we blocked the activation of ERK and p38 MAPK by using the specific inhibitors U0126 and SB203580 respectively, and silenced their expression by transfection of small interfering RNAs (siRNAs). In the present report, we demonstrated that the antiapoptotic action of $\mathrm{E}_{2}$ on $\mathrm{C} 2 \mathrm{C} 12$ skeletal muscle cells exposed to $\mathrm{H}_{2} \mathrm{O}_{2}$ requires ERK and p38 MAPK activation.

\section{Materials and Methods}

\section{Materials}

Anti-actin (1:15000 for western blot and 1:200 for immunocytochemistry) was purchased from Santa Cruz Biotechnology, Inc. (Santa Cruz, CA, USA). Anti-phospho-AKT (Ser473) (1:1000), anti-phospho-BAD (Ser112) (1:1000), anti-SMAC/DIABLO (1:25), anti-ERK1/2 $(1: 1000)$, and anti-p38 MAPK $(1: 1000)$ were purchased from Cell Signaling Technology, Inc. (Danvers, MA, USA). 4',6-diamidine-2'-phenylindole dihydrochloride (DAPI) and MitoTracker Red (MitoTracker Red CMXRos) dyes, and Alexa Fluor 488-conjugated anti-rabbit secondary antibody (1:200) were purchased from Molecular Probes (Eugene, OR, USA). Cytochrome $c$ oxidase assay kit and $\mathrm{E}_{2}$ were purchased from Sigma-Aldrich. The compounds SB203580 and U0126 were purchased from Calbiochem-Novabiochem Corp. (La Jolla, CA, USA). ERK and p38 MAPK siRNA, fluorescein-siRNA transfection control, and TransPass R2 transfection reagent were purchased from New England Biolabs (NEB; Beverly, MA, USA). All the other reagents used were of analytical grade. 


\section{Cell culture and treatment}

C2C12 murine skeletal muscle cells, kindly donated by Dr Enrique Jaimovich (Universidad de Chile, Santiago, Chile), were cultured in growth medium DMEM supplemented with $10 \%$ heat-inactivated $\left(30 \mathrm{~min}, 56^{\circ} \mathrm{C}\right)$ fetal bovine serum, $1 \%$ nystatine, and $2 \%$ streptomycin. Cells were incubated at $37^{\circ} \mathrm{C}$ in a humid atmosphere of $5 \%$ $\mathrm{CO}_{2}$ in air. Cultures were passaged every 2 days with fresh medium. Under these conditions, C2C12 myoblasts resemble the activated satellite cells that surround the mature myofibers and proliferate and differentiate participating in the repair of the tissue when a cellular injury exists (Yoshida et al. 1998). The assays were performed with $70-80 \%$ confluent cultures $\left(120000\right.$ cells $\left./ \mathrm{cm}^{2}\right)$ in medium without serum for $30 \mathrm{~min}$. During this preincubation, cells were exposed to $10 \mu \mathrm{M}$ U0126 or $20 \mu \mathrm{M}$ SB203580 in the experiments indicated. The doses of the compounds used were the most effective to inhibit both MAPKs in C2C12 cells (Ronda et al. 2007). The inhibitors were dissolved in dimethyl sulfoxide (DMSO) at a final concentration of $0 \cdot 1 \%(\mathrm{v} / \mathrm{v})$ and $0 \cdot 2 \%(\mathrm{v} / \mathrm{v})$ respectively. Also, as control, it was verified that DMSO, applied to the myoblasts at the same concentration used in these experiments, did not interfere with the effects of $\mathrm{E}_{2}$ on apoptotic $\mathrm{C} 2 \mathrm{C} 12$ cells. Treatments were carried out by adding $10^{-8} \mathrm{M} \mathrm{E}_{2}$ or vehicle (control: 0.001\% isopropanol) during $45 \mathrm{~min}$ before the induction of apoptosis with $0.5 \mathrm{mM}$ of $\mathrm{H}_{2} \mathrm{O}_{2}$ for $2-3 \mathrm{~h}$. Unless otherwise noted, cells were cultured to $50 \%$ confluence in chamber slides for microscopy.

\section{Janus Green staining}

The supravital Janus Green colorant is a water-soluble dye that is absorbed by the whole cell, staining in a blue-greenish coloration (oxidative state). Nevertheless, this tint disappears in the cytoplasm a few minutes later due to the reductive properties of the cytosol, except in the mitochondria, seen as little dots, where the oxidative environment of the organelle maintains the Janus Green colorant in its oxidative state (blue-greenish coloration; Lazarow \& Cooperstein 1953, Ernster \& Schatz 1981). Janus Green staining can indirectly indicate mitochondrial dysfunction, since any rupture/ disruption of the mitochondrial membrane cause the release of their content to the cytosol inducing colorant oxidation in the cytoplasm. After treatments, the cells were incubated with $0 \cdot 1 \%$ Janus Green in serum-free medium $(1: 2, \mathrm{v} / \mathrm{v})$ during $30 \mathrm{~min}$ at $37^{\circ} \mathrm{C}$. Cells were examined by bright field microscopy.

\section{Mito Tracker Red and DAPI staining}

After treatments, coverslips with adherent cells were stained with MitoTracker Red, which was prepared in DMSO and then added to the cell culture medium at a final concentration of $1 \mu \mathrm{mol} / 1$. After $15-30-\mathrm{min}$ incubation at $37^{\circ} \mathrm{C}$, the cells were washed with PBS ( $\mathrm{pH} 7 \cdot 4,8 \mathrm{~g} / 1 \mathrm{NaCl}, 0 \cdot 2 \mathrm{~g} / 1 \mathrm{KCl}$, $0.24 \mathrm{~g} / 1 \mathrm{KH}_{2} \mathrm{PO}_{4}$, and $\left.1.44 \mathrm{~g} / 1 \mathrm{Na}_{2} \mathrm{HPO}_{4}\right)$ and fixed with methanol at $-20{ }^{\circ} \mathrm{C}$ for $30 \mathrm{~min}$.

For DAPI staining, fixed cells were incubated for $30 \mathrm{~min}$ at room temperature in darkness with 1:500 of a stock solution of DAPI $(5 \mathrm{mg} / \mathrm{ml})$ and washed with PBS. One hundred nuclei were counted for each condition, and apoptotic nuclei were identified as those with reduction in its size (picnosis) or its fragmentation. The percentage of apoptotic nuclei is shown in a graph.

Cells were examined using a fluorescence microscope (NIKON Eclipse Ti-S) equipped with standard filter sets to capture fluorescent signals, and images were collected using a digital camera. Also, samples were analyzed with a confocal scanning laser microscopy (Leica TCS SP2 AOBS microscope), using a $63 \times$ objective.

\section{Immunocytochemistry}

Semi-confluent monolayers were fixed as before. After fixation, cells were rinsed three times with PBS, and nonspecific sites were blocked for $1 \mathrm{~h}$ in $2 \%$ BSA. Cells were incubated with appropriate primary antibodies overnight at $4{ }^{\circ} \mathrm{C}$. The primary antibodies were recognized by fluorophore-conjugated secondary antibodies. Finally, the stained cells were analyzed with a conventional fluorescence microscope or confocal scanning laser microscopy. The specificity of the labeling techniques was proven by the absence of labeling when the primary or the secondary antibodies were omitted.

\section{Western blot analysis}

Cells from 70 to $80 \%$ confluent cultures $\left(120000\right.$ cells $/ \mathrm{cm}^{2}$ ) were lysed using a buffer made of $50 \mathrm{mM}$ Tris- $\mathrm{HCl}, \mathrm{pH} 7 \cdot 4$, $150 \mathrm{mM} \mathrm{NaCl}, 0 \cdot 2 \mathrm{mM} \mathrm{Na} \mathrm{VO}_{4}, 2 \mathrm{mM}$ EDTA, $25 \mathrm{mM}$ $\mathrm{NaF}, 1 \mathrm{mM}$ phenylmethylsulfonyl fluoride (PMSF), $20 \mu \mathrm{g} / \mathrm{ml}$ leupeptin, and $20 \mu \mathrm{g} / \mathrm{ml}$ aprotinin. Lysates were collected by aspiration and centrifuged at $12000 \mathrm{~g}$ for $15 \mathrm{~min}$. The protein content of the supernatant was quantified by the Bradford procedure (Bradford 1976). Then, lysate proteins dissolved in Laemmli (1970) sample buffer (30 $\mathrm{g}$; ca. 2000000 cells) were separated on 10\% SDS-polyacrylamide gels and electrotransferred to polyvinylidene difluoride membranes. Relative migration of unknown proteins was determined by comparison with molecular weight colored markers (Amersham). Membranes were blocked $1 \mathrm{~h}$ at room temperature in PBS-T buffer (PBS 0.1\% Tween-20) containing $5 \%$ dry milk. Membranes were incubated with different primary antibodies overnight at $4{ }^{\circ} \mathrm{C}$, then washed three times in PBS-T and incubated in PBS-T containing 1\% dry milk with peroxidase-conjugated secondary antibodies for $1 \mathrm{~h}$ at room temperature. Next, membranes were visualized using an enhanced chemiluminescent technique according to the manufacturer's instructions. Images were obtained with a GS-700 Imaging Densitomer from Bio-Rad by scanning at 
A

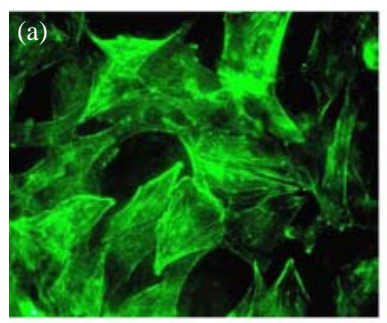

(c)

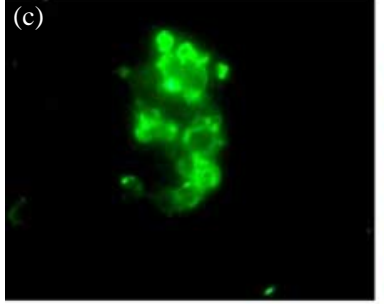

(e)

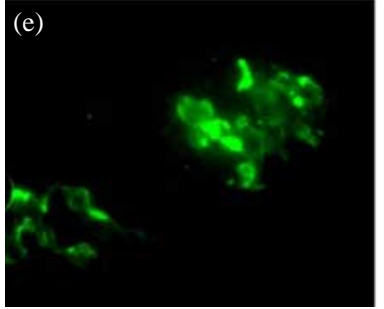

$\mathrm{C}$

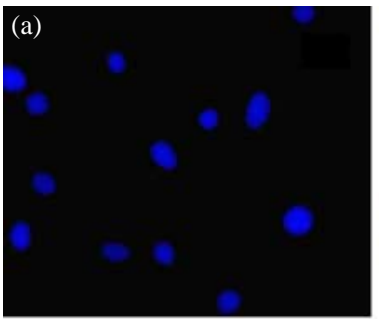

(c)

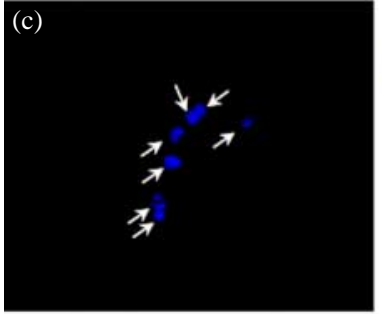

(e)

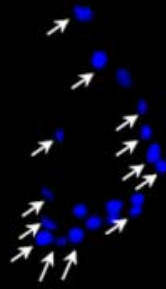

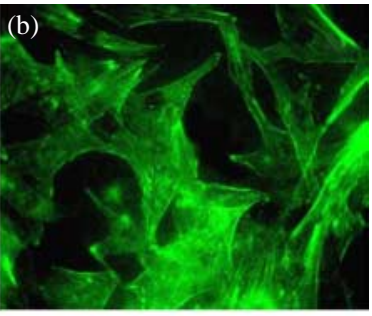
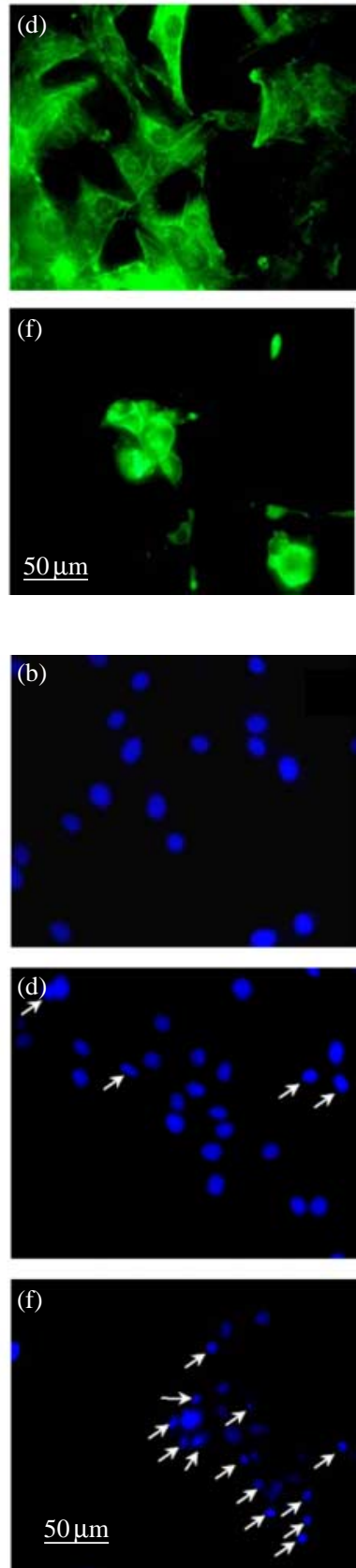

B

(a)
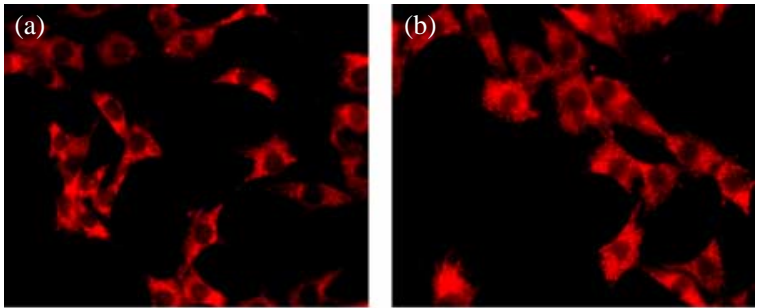

(c)

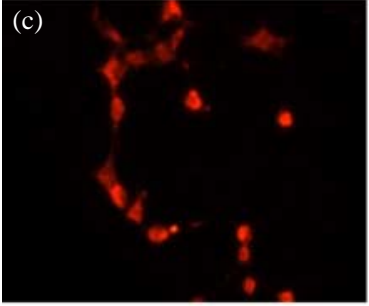

(e)
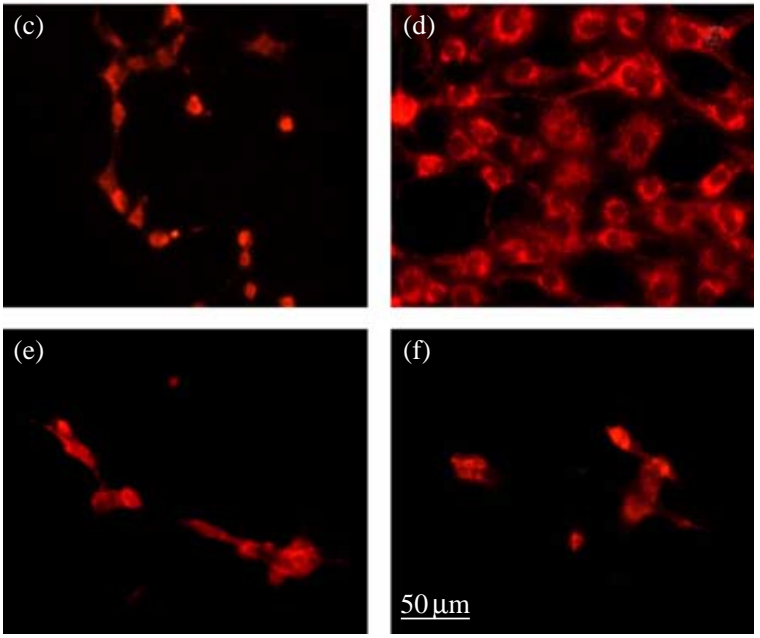

$\mathrm{D}$

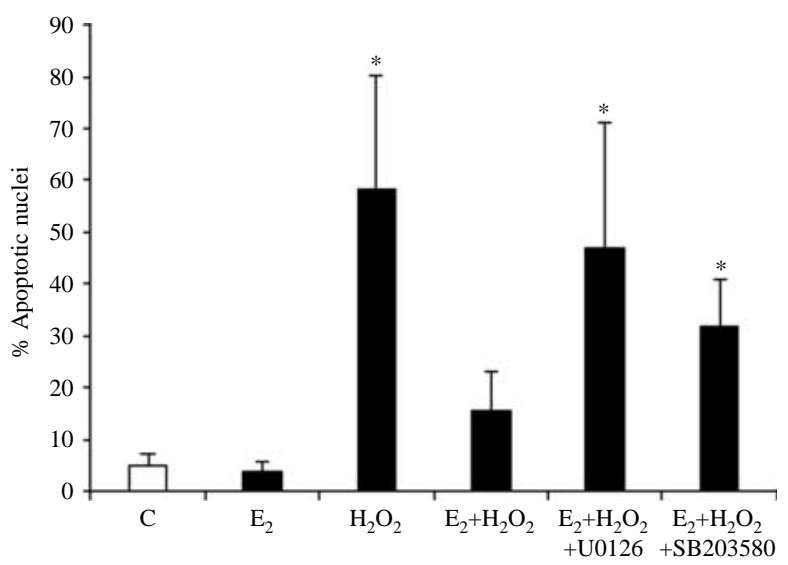


600 dpi. For reprobing with other antibodies, the membranes were incubated in stripping buffer twice $(62.5 \mathrm{mM}$ Tris- $\mathrm{HCl}$, $\mathrm{pH} 6 \cdot 8,2 \% \mathrm{SDS}$, and $50 \mathrm{mM}$ mercaptoethanol) for $30 \mathrm{~min}$ at $55^{\circ} \mathrm{C}$, washed for $10 \mathrm{~min}$ in PBS-T, and then blocked and blotted as described above.

\section{Measurement of outer mitochondrial membrane integrity}

The integrity of outer mitochondrial membranes was evaluated by measuring cytochrome $c$ oxidase activity using a commercially available kit from Sigma (CYTOC-OX1) according to the manufacturer's instructions. Briefly, $\mathrm{C} 2 \mathrm{C} 12$ cells from 70 to $80 \%$ confluent monolayers $\left(120000\right.$ cells $\left./ \mathrm{cm}^{2}\right)$ were scrapped and homogenized in ice-cold TES buffer $(50 \mathrm{mM}$ Tris/ $\mathrm{HCl}, \mathrm{pH} 7 \cdot 4,1 \mathrm{mM}$ EDTA, $250 \mathrm{mM}$ sucrose, $1 \mathrm{mM}$ dithiothreitol, $0.5 \mathrm{mM}$ PMSF, $20 \mu \mathrm{g} / \mathrm{ml}$ leupeptin, $20 \mu \mathrm{g} / \mathrm{ml}$ aprotinin, and $20 \mu \mathrm{g} / \mathrm{ml}$ trypsin inhibitor) using a Teflon-glass hand homogenizer. Lysates were centrifuged at $10000 \boldsymbol{g}$ for $20 \mathrm{~min}$ in order to separate the cytosolic fraction. For cytochrome $c$ oxidase activity measurements, $50 \mu$ l of reduced cytochrome $c(0 \cdot 22 \mathrm{mM})$ were added to $30 \mu \mathrm{l}$ of the lysate (ca. 3000000 cells), and changes in absorbance at $550 \mathrm{~nm}$ were monitored for $1 \mathrm{~min}$. The percentage of cytochrome $c$ activity was calculated using: Units $/ \mathrm{ml}=\Delta \mathrm{Abs} / \mathrm{min}$ $\times$ dil $\times 1 \cdot 1 /$ (vol sample $) \times 21 \cdot 84$, where $\Delta$ Abs $/ \mathrm{min}$ $=\mathrm{Abs} /$ minute $_{\text {sample }}-\mathrm{Abs} /$ minute $_{\text {blank }}$; dil, dilution factor of sample; $1 \cdot 1$, reaction volume in $\mathrm{ml} ; 21 \cdot 84$, extinction coefficient. Differences were calculated by normalizing cytochrome $c$ activity of each condition to that of total protein level obtained by Bradford assay in the same sample. The results were expressed as percentage of mitochondria with damaged outer membrane.

\section{Transfection of siRNA}

Transfection was performed with a culture cellular density reaching $40-60 \%$ confluence with ERK or p38 MAPK siRNA according to the manufacturer's instructions. Briefly, TransPass R2 Transfection Reagent was mixed with each siRNA in serum-free medium. The mix was incubated for $20 \mathrm{~min}$ at room temperature. The culture medium of the cells was aspirated and replaced with the diluted transfection complex mixture. Cells transfected were used in the indicated assays.

\section{Statistical analysis}

Results are shown as means \pm s.E.M. Statistical differences among groups were determined by ANOVA followed by a multiple comparison post hoc test (Scott \& Knott 1974). Data are expressed as significant at $P<0 \cdot 05$.

\section{Results}

ERK and p38 MAPKs mediate the antiapoptotic effects of $E_{2}$ in muscle cells

As a first approach to investigate the contribution of MAPKs to the protective role of estrogens in skeletal muscle cells, morphological characteristics due to apoptosis such as changes in cytoskeleton, mitochondria, and nucleus were studied in C2C12 cells. Regarding the cytoskeleton, images from immunocytochemistry assays performed after treatments using anti-actin antibody (Fig. 1A) show an usual organization of actin filaments in the control condition (panel a) and in cells treated with $\mathrm{E}_{2}\left(10^{-8} \mathrm{M}\right)$ (panel b). When the cultures were exposed to $0.5 \mathrm{mM} \mathrm{H}_{2} \mathrm{O}_{2}$ during $2 \mathrm{~h}$, disorganization of the cytoskeleton was observed (panel c). C2C12 cells incubated with the hormone $45 \mathrm{~min}$ prior to the induction of apoptosis showed actin arrangement similar to that observed in control conditions (panel d). However, disruption of actin filaments by $\mathrm{H}_{2} \mathrm{O}_{2}$ was not reversed by the estrogen in cells treated in the presence of U0126 or SB203580 (panels e and $\mathrm{f}$ ).

During apoptosis, mitochondria also undergo changes in structure and localization. The alterations frequently observed are picnosis, reduction in size, and grouping of these organelles in the perinuclear zone (Desagher \& Martinou 2000, Vasconsuelo et al. 2008). Figure 1B shows that a high proportion $(\sim 70 \%)$ of mitochondria from cultured $\mathrm{C} 2 \mathrm{C} 12$ cells exposed to $0.5 \mathrm{mM} \mathrm{H} \mathrm{H}_{2} \mathrm{O}_{2}$ were clustered over the nucleus (panel c) having lost its characteristic cytoplasmatic distribution observed in the control or in cells treated only with the hormone (panels a and $\mathrm{b}$ respectively). The negative images of the nuclei (see panels a and b) cannot be visualized when cells are treated with $\mathrm{H}_{2} \mathrm{O}_{2}$ (panel c) since mitochondria are covering the nuclear region. Such modification was not observed when the muscle cells were incubated with $\mathrm{E}_{2}\left(10^{-8} \mathrm{M}-45 \mathrm{~min}\right)$ before the induction of apoptosis (panel $\mathrm{d}$ ), in agreement with recent observations

Figure 1 17 $\beta$-Estradiol abrogates $\mathrm{H}_{2} \mathrm{O}_{2}$-induced apoptotic morphology through ERK and p38 MAPK in muscle cells. C2C12 cells were serum-starved for $30 \mathrm{~min}$ in the absence or in the presence of $10 \mu \mathrm{M} \cup 0126$ or $20 \mu \mathrm{M}$ SB203580, and then treated as described in

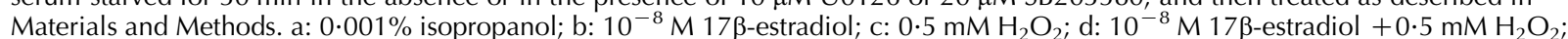
e: $10^{-8} \mathrm{M} 17 \beta$-estradiol $+0 \cdot 5 \mathrm{mM} \mathrm{H}_{2} \mathrm{O}_{2}+10 \mu \mathrm{M}$ U0126; or f: $10^{-8} \mathrm{M} 17 \beta$-estradiol $+0 \cdot 5 \mathrm{mM} \mathrm{H}_{2} \mathrm{O}_{2}+20 \mu \mathrm{M}$ SB203580. Actin was labeled using an anti-actin polyclonal antibody and then using an Alexa Fluor 488-conjugated secondary antibody (green fluorescence) (A). Mitochondria were stained with MitoTracker Red (red fluorescence) (B), and cell nuclei were visualised with DAPI (blue fluorescence) as described in Materials and Methods (C). At least ten fields per slide of three independent experiments were examined. Representative photographs are shown. Magnification $400 \times$. (D) Quantification of apoptotic nuclei. Averages \pm S.E.M. are given, ${ }^{*} P<0 \cdot 05$ respect to the control. Full colour version of this figure available via http://dx.doi.org/10.1677/JOE-09-0429. 

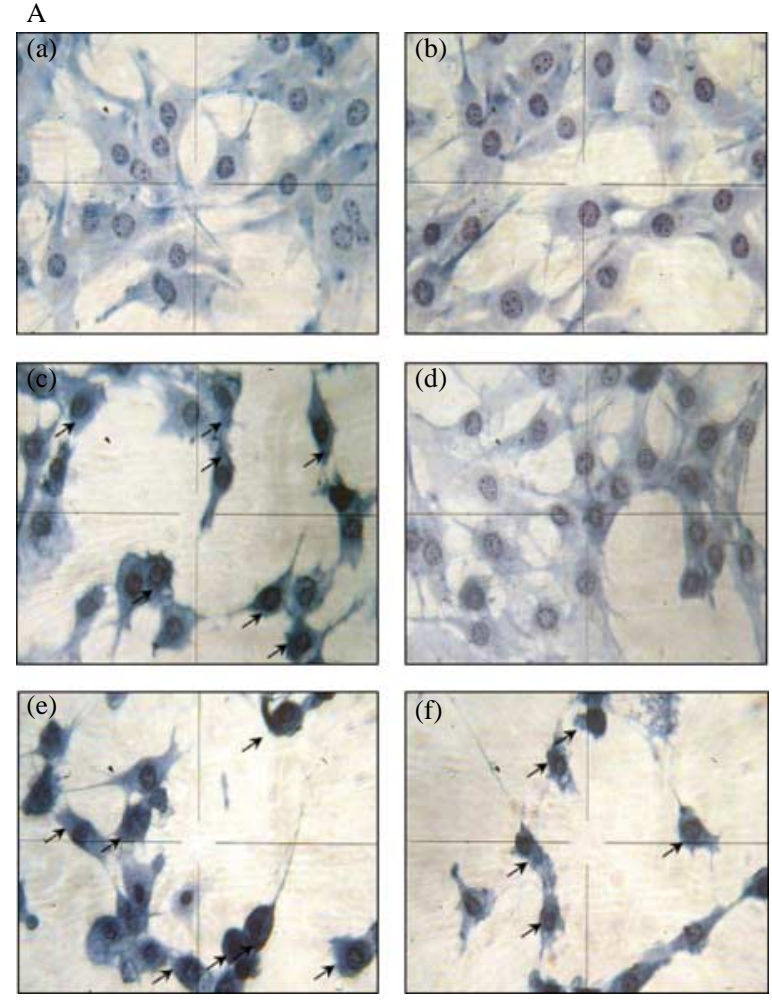

D
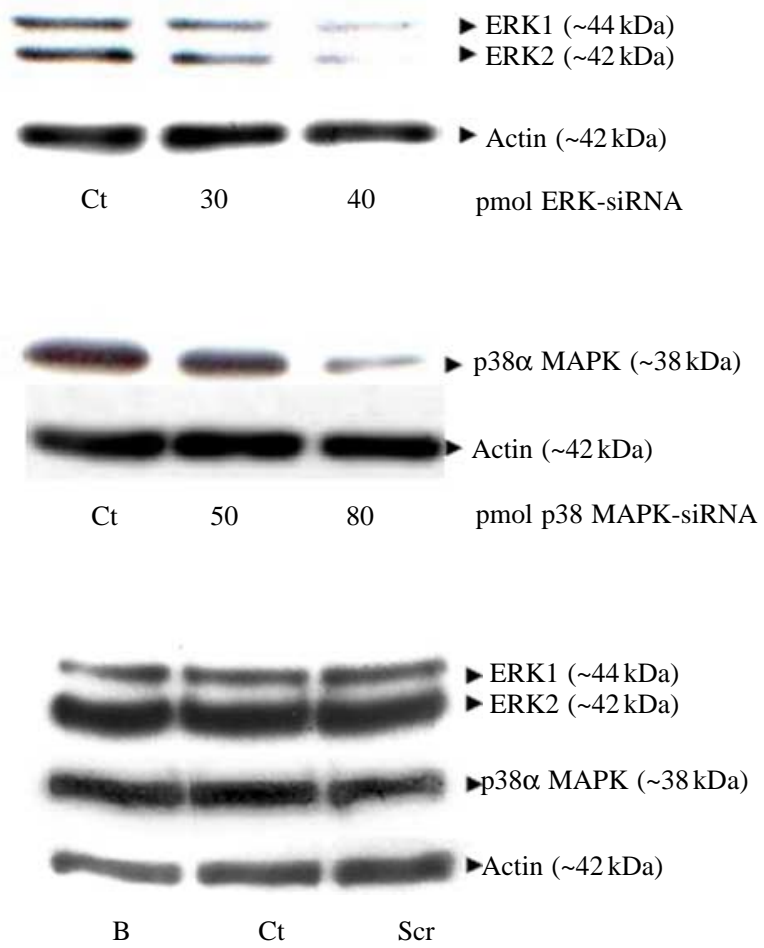

B

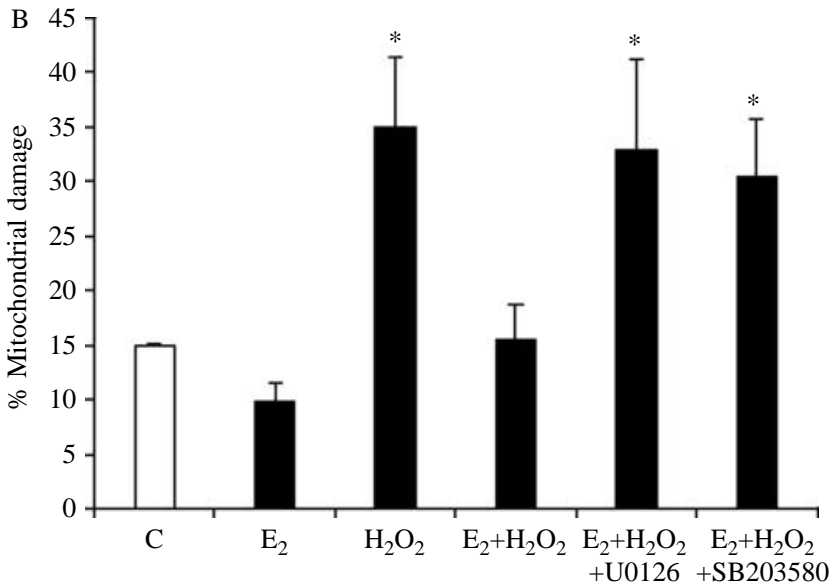

$\mathrm{C}$

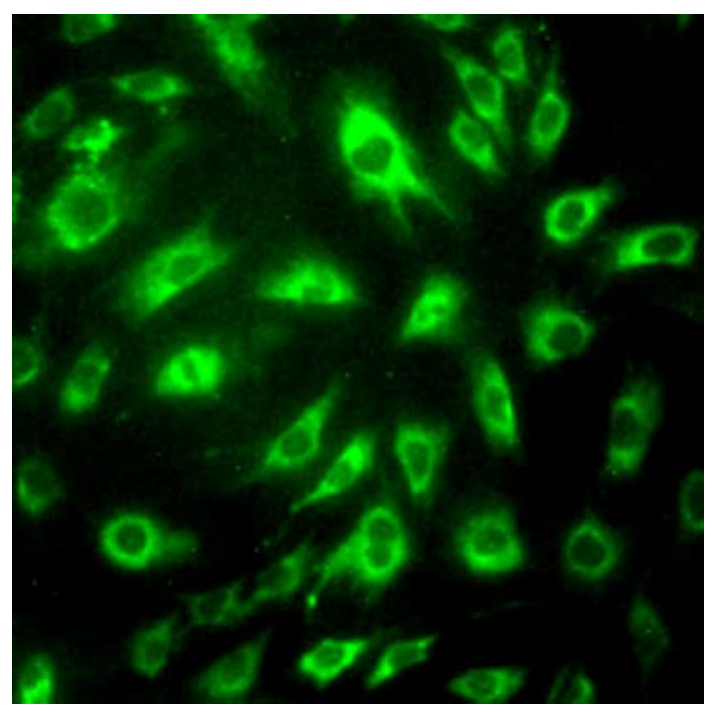

E

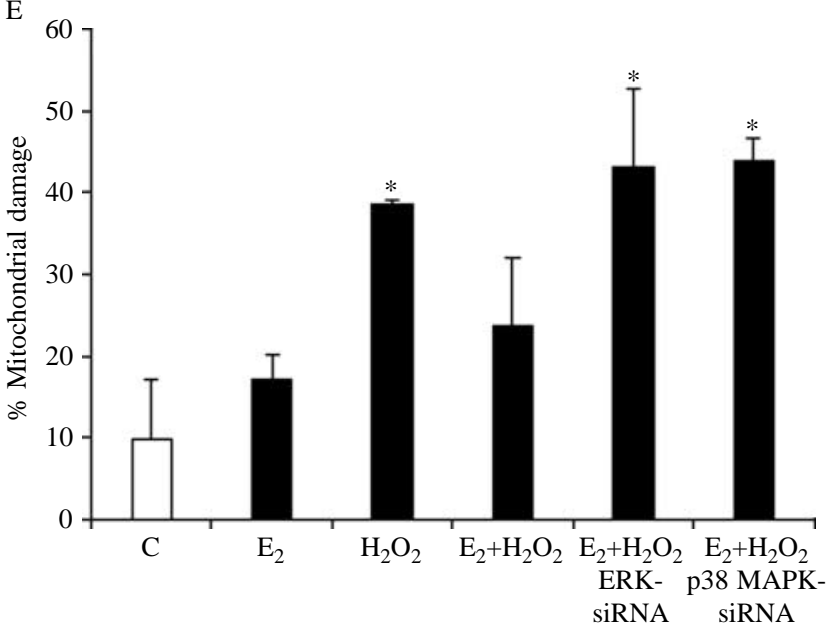


(Vasconsuelo et al. 2008). When cultures were preincubated with U0126 or SB203580 and then treated with the estrogen and $\mathrm{H}_{2} \mathrm{O}_{2}$, mitochondria showed similar abnormalities in intracellular distribution than in apoptotic C2C12 cells (panels e and f). Also, we observed picnosis and reduced size of mitochondria by confocal microscopy in cells exposed to $\mathrm{H}_{2} \mathrm{O}_{2}$ or to the hormone and the oxidative stimuli in the presence of MAPK inhibitors (data not shown).

Next, changes in morphology of nuclei from C2C12 cells treated under the different experimental conditions described above were investigated using the specific nuclear dye DAPI. Apoptotic cells were identified by the condensation and/or fragmentation of their nuclei (indicated with white arrows). In Fig. 1D, the results are expressed as percentage of apoptotic cells. Figure 1C shows intact/normal nuclei of the cells in the control condition (panel a), and treated with $10^{-8} \mathrm{M} \mathrm{E}_{2}$ (panel b). The cultures exposed to $0.5 \mathrm{mM}$ of $\mathrm{H}_{2} \mathrm{O}_{2}$ exhibited the typical apoptotic morphological changes in $\sim 60 \%$ of nuclei consisting in nuclear fragmentation or condensation as shown in Fig. 1D; typical pyknotic nuclei corresponding to these observations are shown in Fig. 1C (panel c). This effect was not observed in cells incubated with the hormone during $45 \mathrm{~min}$ prior to the exposure to $\mathrm{H}_{2} \mathrm{O}_{2}$, which presented mostly normal nuclear morphology $(\sim 15 \%$ apoptotic nuclei) (panel d). These results are in accord with our recent work (Vasconsuelo et al. 2008). However, when the cultures were treated with MAPK inhibitors followed by the hormone and $\mathrm{H}_{2} \mathrm{O}_{2}$, as before, the cells showed nuclear fragmentation or condensation ( $\sim 45 \%$ and $\sim 35 \%$ for U0126 or SB203580 respectively) (panels e and f; Fig. 1D). Of relevance, using a similar experimental approach, we observed that $E_{2}$ also prevents via MAPKs the apoptotic morphological changes in cytoskeleton, mitochondria, and nucleus induced by $\mathrm{H}_{2} \mathrm{O}_{2}$ in primary cultures of mouse skeletal muscle cells (data not shown).
Although the use of U0126 and SB203580 is an effective tool to inhibit ERK and p38 MAPK activation respectively, it was considered of importance to exclude the possibility that these inhibitors were inductive of apoptosis per se in our cellular cultures. The effect of each inhibitor during at least $5 \mathrm{~h}$ was evaluated on the structure of mitochondria and nuclei, and we found that each inhibitor did not induce the apoptotic changes described before (data not shown).

\section{ERK and $p 38$ MAPKs play a role in the protective effects of} $E_{2}$ on mitochondrial membrane integrity in muscle cells

In the intrinsic pathway of apoptosis, different signals lead to alterations/loss of mitochondrial membrane permeability with the subsequent release of proapoptotic factors such as cytochrome $c$ (Liu et al. 1996) and SMAC/DIABLO (Shiozaki \& Shi 2004). $E_{2}$ inhibits the rupture of the outer mitochondrial membrane which prevents cytochrome $c$ release (Vasconsuelo et al. 2008). With the aim to study the role of ERK and p38 MAPK in $\mathrm{E}_{2}$-induced mitochondrial membrane protection, firstly, functional changes of mitochondria were evaluated using supravital Janus Green staining. The images in Fig. 2A show that C2C12 murine muscle cells exposed to $0.5 \mathrm{mM} \mathrm{H}_{2} \mathrm{O}_{2}$ during $2 \mathrm{~h}$ (panel c) exhibited a darker blue-greenish coloration in all the cytoplasm than the control (panel a) or cells treated with $10^{-8} \mathrm{M} \mathrm{E}_{2}$ (panel b), where mitochondria appear as little blue-greenish dots with cytoplasmic distribution and around the nucleus. These results indicate that rupture of the mitochondrial membrane by $\mathrm{H}_{2} \mathrm{O}_{2}$ caused liberation of its content to the cytoplasm, inducing the oxidation of the colorant. Black arrows in the figure indicate the oxidation of the colorant in the cytoplasm (blue-greenish coloration) due to the liberation of mitochondrial content (Ernster \& Schatz 1981). This effect was not observed when $\mathrm{C} 2 \mathrm{C} 12$ cells were preincubated with the

Figure 2 17 3 -Estradiol inhibits mitochondrial membrane damage via ERK and p38 MAPK activation in muscle cells. (A) C2C12 cell cultures with a $60-70 \%$ confluence were treated as in Fig. 1: a: $0 \cdot 001 \%$ isopropanol; b: $10^{-8} \mathrm{M} 17 \beta$-estradiol; c: $0 \cdot 5 \mathrm{mM} \mathrm{H} \mathrm{O}_{2} ; \mathrm{d}: 10^{-8} \mathrm{M}$

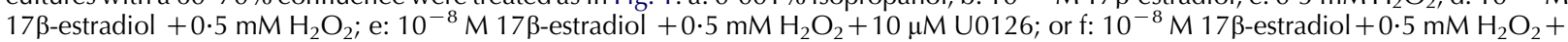
$20 \mu \mathrm{M}$ SB203580. Then, cells were stained in vivo with Janus Green as described in Materials and Methods. At least ten fields per slide of three independent cultures were examined. Representative photographs are shown. Magnification $400 \times$. (B) C2C12 cells were preincubated with $0 \cdot 001 \%$ isopropanol $(C)$ or $10^{-8} \mathrm{M} 17 \beta$-estradiol $\left(E_{2}\right)$ in the presence or in the absence of $10 \mu \mathrm{M} \cup 0126$ or $20 \mu \mathrm{M}$ SB203580 as described in previous experiments. The cultures were then treated with $0.5 \mathrm{mM} \mathrm{H}_{2} \mathrm{O}_{2}$ or $10^{-8} \mathrm{M} 17 \beta$-estradiol $+0 \cdot 5 \mathrm{mM}$ $\mathrm{H}_{2} \mathrm{O}_{2}$ with or without $\cup 0126$ or SB203580. Membrane mitochondrial damage was evaluated by measuring cytochrome $c$ oxidase activity as described in Materials and Methods. Averages \pm s.E.M. are given, $* P<0 \cdot 05$ respect to the control. (C) siRNA transfection efficiency was estimated using fluorescein-siRNA transfection control and TransPass R2 transfection reagent. Cells were visualized $24 \mathrm{~h}$ post transfection. Total cells were first counted using light microscopy, and then, green fluorescent cells were counted in the same field with a conventional microscope employing an adequate filter for green fluorescence. The percentage of fluorescent cells (transfected) was calculated with respect to the total cells observed by light microscopy (more of $80 \%$ cells presented green fluorescence). A typical pattern of fluorescence with fluorescein siRNA is shown. Magnification $400 \times$. (D) C2C12 cells were transiently transfected with or without TransPass R2 transfection reagent (Ct: control TransPass and B: basal respectively) and 30/40 pmol of ERK siRNA (upper panel), 50/80 pmol of p38 MAPK siRNA (middle panel), or 20 pmol of fluorescent probe as scramble control (Scr) (lower panel). Expression of each MAPK was analyzed $24 \mathrm{~h}$ post transfection by western blot analysis as described in Materials and Methods. Immunoblots of total cell lysates employing anti-ERK1/2 or anti-p38 MAPK antibodies are shown. Actin loading control was detected using anti-actin polyclonal antibody. (E) C2C12 cells were transiently transfected with 40 pmol of ERK siRNA or 80 pmol of p38 MAPK siRNA as described in Materials and Methods. Transfected cultures were treated with $0 \cdot 001 \%$ isopropanol $(\mathrm{C})$ or $10^{-8} \mathrm{M} 17 \beta$-estradiol $\left(\mathrm{E}_{2}\right)$ during $45 \mathrm{~min}$, and then, cells were exposed to $0 \cdot 5 \mathrm{mM}$ $\mathrm{H}_{2} \mathrm{O}_{2}$ or $10^{-8} \mathrm{M} 17 \beta$-estradiol $+0.5 \mathrm{mM} \mathrm{H}_{2} \mathrm{O}_{2}\left(\mathrm{E}_{2}+\mathrm{H}_{2} \mathrm{O}_{2}\right)$. Cytochrome $c$ oxidase activity was measured as described in Materials and Methods. Results are representative of three independent experiments. Averages \pm s.E.M. are given, ${ }^{*} P<0 \cdot 05$ respect to the control. Full colour version of this figure available via http://dx.doi.org/10.1677/JOE-09-0429. 
hormone $\left(10^{-8} \mathrm{M}-45 \mathrm{~min}\right)$ prior to $\mathrm{H}_{2} \mathrm{O}_{2}$ treatment (panel d). However, when the muscle cells were exposed to the ERK or p38 MAPK inhibitors (U0126 and SB203580 respectively), and then to $\mathrm{E}_{2}$ and $\mathrm{H}_{2} \mathrm{O}_{2}$, Janus Green oxidation in the cytoplasm was observed again (black arrows in panels e and f).

To confirm the effects of the hormone on mitochondrial membrane integrity, we measured cytochrome $c$ oxidase activity in the cytosolic fraction and SMAC/DIABLO release in the presence and in the absence of MAPK inhibitors. The results of cytochrome $c$ oxidase activity assays shown in Fig. $2 \mathrm{~B}$ indicate that $\mathrm{H}_{2} \mathrm{O}_{2}$ increases mitochondrial damage which is blocked by pre-incubation of the cells with $\mathrm{E}_{2}$ as observed before (Vasconsuelo et al. 2008). Interestingly, the hormone was unable to exert protective effects at the mitochondrial level when ERK and p38 MAPKs were inhibited. To strengthen these findings, we evaluated the mitochondrial functional status in $\mathrm{C} 2 \mathrm{C} 12$ cells transfected with specific siRNAs to induce silencing of each MAPK. Optimum transfection conditions were established using fluorescein siRNA $(\geq 80 \%$ after $24-\mathrm{h}$ incubation with 20 pmol of fluorescent probe; Fig. 2C). To verify silencing efficiency, we examined the expression levels of ERK and p38 MAPKs after transfection with siRNAs (24 h with $30 / 40$ pmol for ERK siRNA and 50/80 pmol for p38 MAPK siRNA). Figure 2D (upper and middle panels) reveals that each siRNA probe led to a significant suppression in the levels of both MAPK proteins. The siRNAs used were highly specific. As a scramble control (Scr), we employed the fluorescein-siRNA probe of the kit (chemically synthesized 21-bp RNA which has no sequence identity to any mammalian sequences) and blockage of ERK or p38 MAPK protein levels was not observed (Fig. 2D, lower panel). Under these conditions, we investigated cytochrome $c$ oxidase activity as before and obtained similar results than using specific inhibitors (Fig. 2E). SMAC/DIABLO location under the above experimental condition was investigated by immunocytochemical assays using an antibody against SMAC/DIABLO (green fluorescence) and staining mitochondria with Mitotracker probe (red fluorescence). The images obtained by confocal microscopy presented in Fig. 3 show that in control C2C12 cells (panel a) or treated with the hormone (panel b), SMAC/DIABLO was located exclusively within mitochondria, demonstrated by the mixture of fluorescences in yellow color (merge). Exposure of cultures to $0.5 \mathrm{mM} \mathrm{H}_{2} \mathrm{O}_{2}$ during $2 \mathrm{~h}$ promoted SMAC/DIABLO release from mitochondria (panel c); this effect was reversed in cells preincubated with $\mathrm{E}_{2}\left(10^{-8} \mathrm{M}-45 \mathrm{~min}\right)$ (panel d). When ERK and p38 MAPKs were inhibited using U0126 or SB203580, as before, the estrogen did not prevent SMAC/ DIABLO liberation (panels e and $\mathrm{f}$ ).

\section{$E_{2}$ regulates the $P I 3 K / A K T / B A D$ pathway through $E R K$ and} p38 MAPK in muscle cells

We have recently shown that $\mathrm{E}_{2}$ is able to activate the $\mathrm{PI} 3 \mathrm{~K} / \mathrm{AKT}$ pathway which modulates BAD phosphorylation,
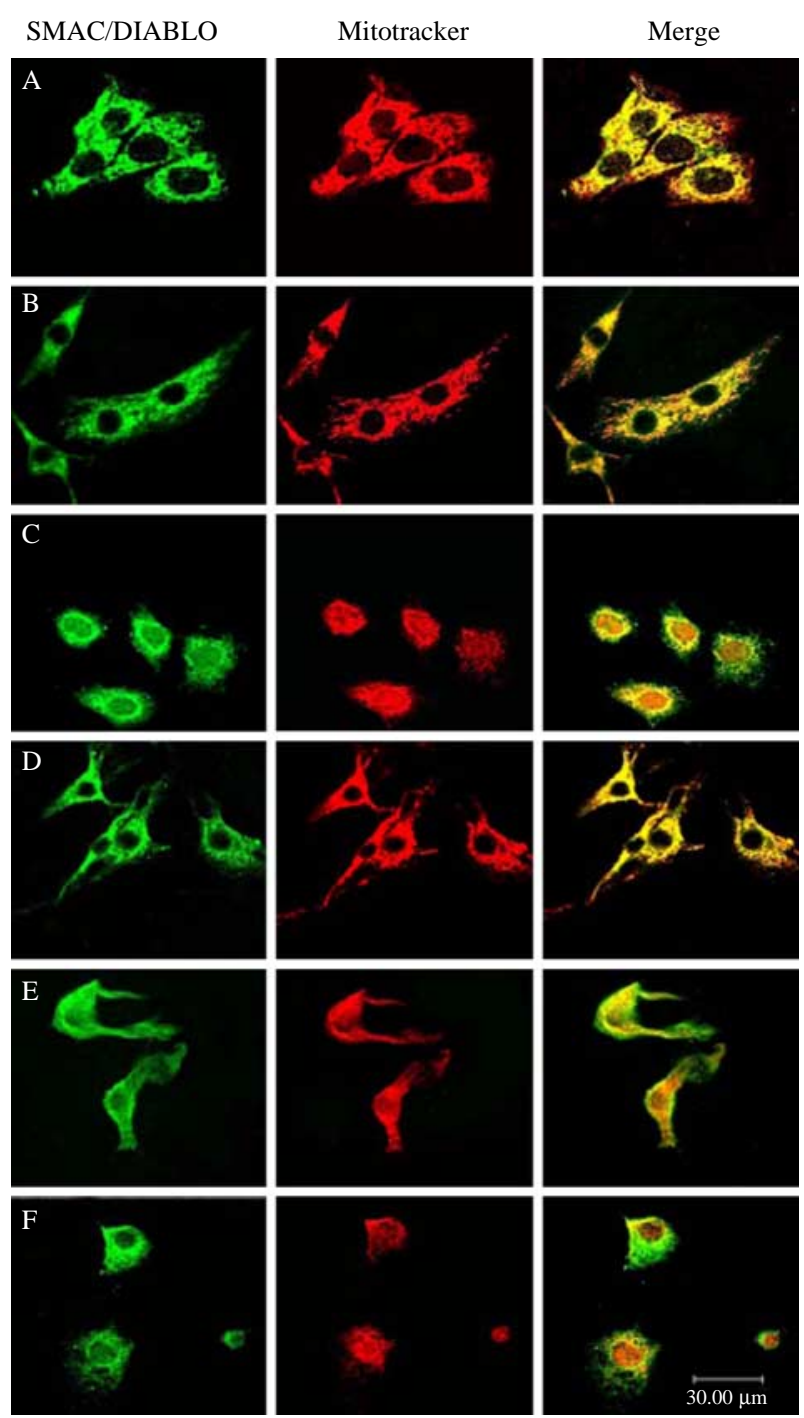

Figure $317 \beta$-Estradiol blocks $\mathrm{H}_{2} \mathrm{O}_{2}$-dependent SMAC/DIABLO release through the activation of MAPKs in muscle cells. Mitochondria of C2C12 cells were stained with Mitotracker Red (red fluorescence), and immunocytochemical assays were performed by confocal microscopy using anti-SMAC/DIABLO antibody (green fluorescence). a: $0 \cdot 001 \%$ isopropanol; b: $10^{-8} \mathrm{M}$ 17ß-estradiol; c: $0.5 \mathrm{mM} \mathrm{H}_{2} \mathrm{O}_{2}$; d: $10^{-8} \mathrm{M} 17 \beta$-estradiol + $0.5 \mathrm{mM}$ $\mathrm{H}_{2} \mathrm{O}_{2}$; e: $10^{-8} \mathrm{M} \mathrm{17 \beta -estradiol}+0.5 \mathrm{mM} \mathrm{H}_{2} \mathrm{O}_{2}+10 \mu \mathrm{M}$ U0126; or f: $10^{-8} \mathrm{M} 17 \beta$-estradiol $+\mathrm{H}_{2} \mathrm{O}_{2} 0.5 \mathrm{mM}+20 \mu \mathrm{M} \mathrm{SB} 203580$. At least ten fields per slide were examined. Representative photographs are shown. Magnification $630 \times$. Full colour version of this figure available via http://dx.doi.org/10.1677/JOE-09-0429.

and thereby, the hormone can prevent apoptosis induced by $\mathrm{H}_{2} \mathrm{O}_{2}$ in $\mathrm{C} 2 \mathrm{C} 12$ skeletal muscle cells (Vasconsuelo et al. 2008). In view that ERK and p38 MAPKs participate in the antiapoptotic effects of the hormone, we next examined the role of both MAPKs in AKT and BAD phosphorylation stimulated by the estrogen in the presence of U0126 and SB203580 inhibitors. 
The western blot analysis from Fig. 4A shows that $E_{2}$ induces AKT phosphorylation both in the absence or in the presence of $\mathrm{H}_{2} \mathrm{O}_{2}$ as reported before (Vasconsuelo et al. 2008). However, when the cells were preincubated with ERK inhibitor (U0126) or p38 MAPK inhibitor (SB203580), the hormone was not able to stimulate AKT phosphorylation. Phospho-AKT inactivates BAD in C2C12 muscle cells by the phosphorylation of its Ser136 residue (Vasconsuelo et al. 2008). It is also known that the proapoptotic protein BAD can

A
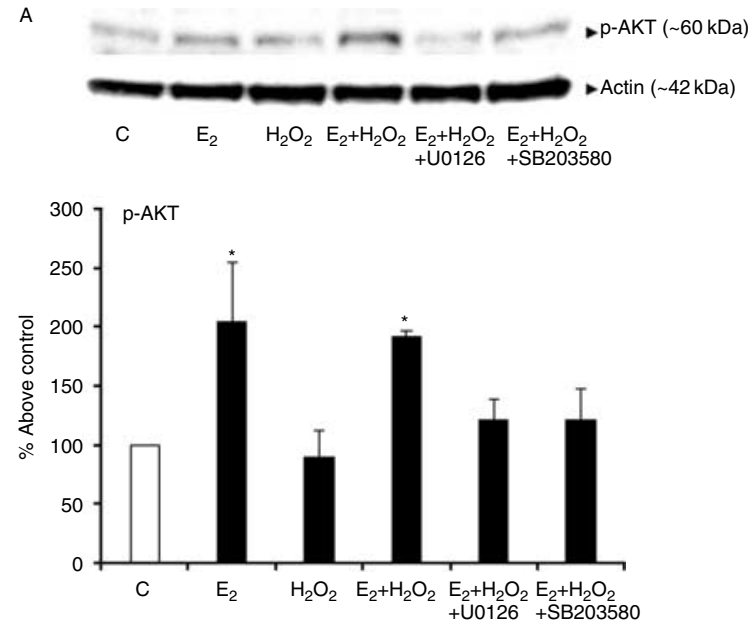

B
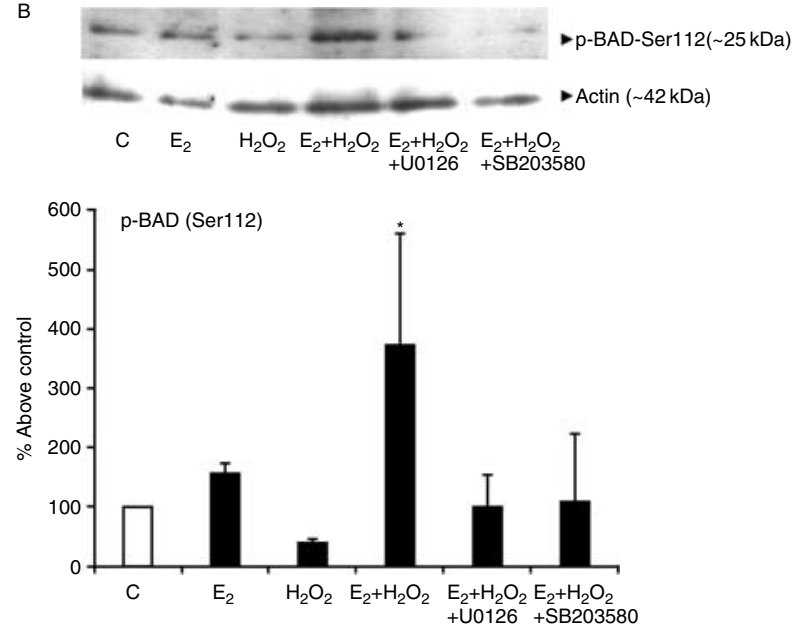

Figure 4 17 $\beta$-Estradiol-induced AKT and BAD phosphorylation involves the ERK and p38 MAPK pathways in muscle cells. C2C12 cells were incubated with $0.001 \%$ isopropanol (C) or $10^{-8} \mathrm{M} 17 \beta$ estradiol $\left(E_{2}\right)$ in the presence or in the absence of $10 \mu \mathrm{M} \cup 0126$ or $20 \mu \mathrm{M}$ SB203580 as described in Materials and Methods. The cultures were then treated with $0.5 \mathrm{mM} \mathrm{H}_{2} \mathrm{O}_{2}$ or $0.5 \mathrm{mM} \mathrm{H}_{2} \mathrm{O}_{2}+$ $10^{-8} \mathrm{M} 17 \beta$-estradiol with or without $10 \mu \mathrm{M} \cup 0126$ or $20 \mu \mathrm{M}$ SB203580. Cell lysates were prepared and subjected to western blot analysis using anti-phospho-AKT (A) and anti-phospho-BAD (Ser112) (B) antibodies. Total actin levels were measured as protein loading control. Blots are representative of three independent experiments. Densitometric quantification of blots is shown. Averages \pm S.E.M. are given; ${ }^{*} P<0.05$ respect to the control. be inhibited by phosphorylation at serine 112 (Ser112) by ERK (Fang et al. 1999, Shimamura et al. 2000), therefore the role of each MAPK in the inactivation of BAD through this particular residue was investigated. Incubation of the cells with the hormone $\left(10^{-8} \mathrm{M}-45 \mathrm{~min}\right)$ prior to treatment with the oxidative stimuli increased the phosphorylation of this proapoptotic protein. When the inhibitors of MAPKs were used, this effect of the hormone was blocked (Fig. 4B).

\section{Discussion}

Rapid signaling cascades triggered by $E_{2}$ regulate various cellular processes such as differentiation, proliferation, and even apoptosis (Razandi et al. 2000, Manolagas \& Kousteni 2001, Acconcia \& Marino 2003). Particularly, MAPKs are key components modulating these events (Pearson et al. 2001). In cellular death, it has been demonstrated that ERK activation is related to cell survival in response to mitogenic factors, while stimulation of p38 MAPK has been associated with the promotion of apoptosis (Wada \& Penninger 2004). The results presented here provide evidence demonstrating the contribution of both ERK and p38 MAPKs to the protective effects of $\mathrm{E}_{2}$ in $\mathrm{H}_{2} \mathrm{O}_{2}$-induced apoptosis in the C2C12 muscle cell line. Thus, in the presence of ERK and p38 MAPK inhibitors, U0126 and SB203580 respectively, the hormone could not prevent the characteristic alterations observed in $\mathrm{C} 2 \mathrm{C} 12$ cells during apoptosis consisting in disorganization of actin filaments, changes in mitochondrial intracellular distribution, and nuclear condensation/fragmentation. In agreement with our results, it has been observed in neuronal cells that ERK and p38 MAPKs mediate the antiapoptotic effects of $\mathrm{E}_{2}$ (Alexaki et al. 2006).

The proapoptotic member of the BCL2 family, BAD, is inactivated by phosphorylation at its four serine residues (112, 136, 155, and 170), and is then sequestered in the cytosol by the 14-3-3 protein. In response to an apoptotic stimulus, BAD is dissociated from 14-3-3 protein by dephosphorylation, which enables it to form a complex with proapoptotic members in mitochondria leading to cellular death (Yang et al. 1995, Zha et al. 1996, Lizcano et al. 2000). Several signaling cascades can promote the phosphorylation and inactivation of $\mathrm{BAD}$, one of them is the PI3K/AKT pathway (Downward 2004). We have previously demonstrated that $\mathrm{E}_{2}$ exerts its protective effects by activating $\mathrm{PI} 3 \mathrm{~K} / \mathrm{AKT}$ and in turn BAD phosphorylation at Ser136 in C2C12 cells (Vasconsuelo et al. 2008). Fernando \& Wimalasena (2004) also reported that the PI3K/AKT/BAD pathway mediates the antiapoptotic action of $\mathrm{E}_{2}$ in breast cancer cells. In these studies, we investigated whether the activation of MAPKs by $E_{2}$ was implicated in such mechanism. We found that the estrogen could not induce AKT and BAD (Ser112) phosphorylation when the MAPKs were inhibited using U0126 or SB203580 compounds. This fact suggests that the ERK and p38 MAPK signaling pathways are involved in AKT stimulation induced by the steroid. 


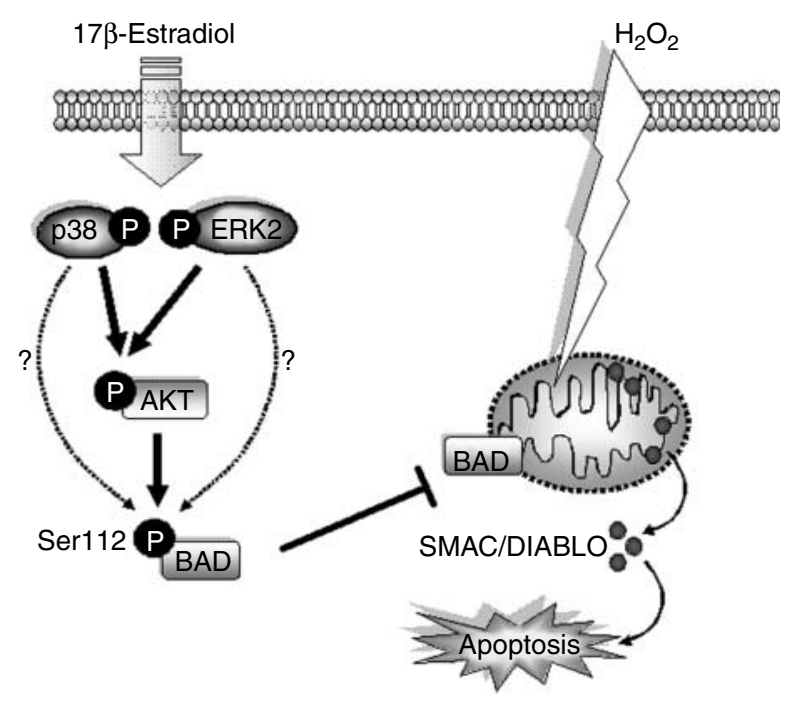

Figure 5 Schematic diagram depicting the role of ERK and p38 MAPK in the antiapoptotic effects of $17 \beta$-estradiol in muscle cells. In myoblastic cells, $17 \beta$-estradiol induces ERK and p38 MAPK phosphorylation, which are involved in AKT stimulation and BAD inactivation. This mechanism is implicated in the antiapoptotic action of $17 \beta$-estradiol abrogating mitochondrial membrane damage, and consequently SMAC/DIABLO release, induced by hydrogen peroxide.

Accordingly, in hepatic cells, it has been verified that AKT activation is modulated by the estrogen via ERK acting on PTEN levels (Marino et al. 2003). In addition, p38 MAPK is a positive regulator of AKT activation inhibiting the neutrophil apoptotic process (Rane \& Klein 2009). Generally, BAD phosphorylation in Ser136 is associated with PI3K-AKT activity, whereas BAD phosphorylation in Ser112 is related with an action of ERK through the phosphorylation of RSKs (Zhu et al. 2002, Ahn et al. 2009). In these studies, the fact that U0126 and SB203580 inhibitors abrogated AKT and BAD (Ser112) phosphorylation modulated by $\mathrm{E}_{2}$ suggests a new mechanism for muscle cells, in which hormone activation of MAPKs may alternatively phosphorylate BAD (Ser112) via AKT. Interestingly, it has been reported in L6 myotubes that BAD (Ser112) phosphorylation induced by insulin is mediated to a greater extent by the PI3K/AKT pathway rather than the ERK-RSK pathway (Gao et al. 2008). However, the possibility that the estrogen may regulate BAD (Ser112) phosphorylation through an effect of ERK-RSK pathway cannot be definitely excluded by the present experiments. Clearly, further studies are necessary in order to understand the estrogen survival signaling mechanism that involves MAPK and AKT/BAD pathways.

Mitochondria play an important function in the regulation of apoptotic events (Desagher \& Martimou 2000, Lu et al. 2007). We have previously shown that they are key cellular sites modulating the protective action of $\mathrm{E}_{2}$ in skeletal muscle cells (Vasconsuelo et al. 2008). These observations are supported by the fact that the mitochondria of these cells express estrogen receptors suggesting that this organelle could be a target for the hormone (Milanesi et al. 2008). In agreement with this interpretation, a central role for mitochondria has been demonstrated in the protective effects of the estrogen in neuronal cells (Simpkins et al. 2005). In this work, the use of the MAPK inhibitors, U0126 and SB203580, demonstrated that the hormone preserves the mitochondrial membrane integrity through an ERK and p38 MAPK - dependent mechanism. This observation was confirmed when ERK and p38 MAPKs were blocked with specific siRNAs, and then, $E_{2}$ was not able to protect mitochondrial membrane integrity against apoptotic stimuli. As mentioned before, it is well established that loss of mitochondrial membrane integrity during apoptosis results in release of proapoptotic factors into the cytosol such as SMAC/DIABLO (Shiozaki \& Shi 2004). The fact that $\mathrm{E}_{2}$ could not prevent $\mathrm{H}_{2} \mathrm{O}_{2}$-induced SMAC/DIABLO liberation in the presence of $\mathrm{U} 0126$ and SB203580, strengthen our hypothesis that the beneficial role of the hormone on mitochondria stability is mediated by the modulation of the ERK and p38 MAPK signaling pathways. These events together with the fact that $\mathrm{E}_{2}$ induces $\mathrm{BAD}$ inactivation by phosphorylation in Ser136 (Vasconsuelo et al. 2008) and Ser112 (this work), suggest a relevant effect of the hormone blocking the intrinsic apoptotic cascade. A possible action of $\mathrm{E}_{2}$ on extrinsic apoptotic pathways should also be taken into account in future investigations.

Finally, the results presented in this work suggest that the hormone plays a role in the survival of satellite myoblasts associated with the myofibers. Accordingly, it has been reported that apoptosis exerts a control on the relative proportion of the myoblast and myotube pools in skeletal muscle (Sandri \& Carraro 1999, Marzetti \& Leeuwenburg 2006). Our data expand the knowledge about the antiapoptotic molecular mechanism activated by $\mathrm{E}_{2}$ via ERK and p38 MAPK (Fig. 5). Clearly, more studies are necessary to fully characterize the antiapoptotic action of $E_{2}$ on skeletal muscle. The elucidation of such mechanism may provide useful insights for understanding the etiology of sarcopenia associated with the deregulation of estrogen levels.

\section{Declaration of interest}

The authors declare that there is no conflict of interest that could be perceived as prejudicing the impartiality of the research reported.

\section{Funding}

This work was supported by grants from the Consejo Nacional de Investigaciones Científicas y Técnicas (CONICET) and the Universidad Nacional del Sur, Argentina. ACR is a recipient of a postdoctoral research fellowship from CONICET. AV and RB are members of CONICET Investigator Career. 


\section{References}

Acconcia F \& Marino M 2003 Synergism between genomic and non genomic estrogen action mechanisms. IUBMB Life 55 145-150.

Ahn S, Kim J, Hara MR, Ren XR \& Lefkowitz RJ 2009 ß-Arrestin-2 mediates anti-apoptotic signaling through regulation of BAD phosphorylation. Journal of Biological Chemistry 284 8855-8865.

Alexaki VI, Charalampopoulos I, Kampa M, Nifli AP, Hatzoglou A, Gravanis A \& Castanas E 2006 Activation of membrane estrogen receptors induce pro-survival kinases. Journal of Steroid Biochemistry and Molecular Biology $\mathbf{9 8}$ 97-110.

Bradford MM 1976 A rapid and sensitive method for the quantitation of microgram quantities of protein utilizing the principle of protein-dye binding. Analytical Biochemistry 72 248-254.

Chevion M, Berenshtein E \& Stadtman ER 2000 Human studies related to protein oxidation: protein carbonyl content as a marker of damage. Free Radical Research 33 99-108.

Dean RT, Fu S, Stocker R \& Davies MJ 1997 Biochemistry and pathology of radical-mediated protein oxidation. Biochemical Journal 324 1-18.

Desagher S \& Martinou J 2000 Mitochondria as the central control point of apoptosis. Trends in Cell Biology 10 369-377.

Dionne I, Kinaman K \& Poehlman E 2000 Sarcopenia and muscle function during menopause and hormone-replacement therapy. Journal of Nutrition, Health \& Aging 4 156-161.

Dirks A \& Leeuwenburgh C 2002 Apoptosis in skeletal muscle with aging. American Journal of Physiology. Regulatory, Integrative and Comparative Physiology 282 519-527.

Downward J 2004 PI-3kinase, Akt and cell survival. Seminars in Cell and Developmental Biology 15 177-182.

Ernster L \& Schatz G 1981 Mitochondria: a historical review. Journal of Cell Biology 91 227-255.

Fang X, Yu S, Eder A, Mao M, Bast R, Boyd D \& Mills G 1999 Regulation of Bad phosphorylation at serine 112 by the Ras-mitogen-activated protein kinase pathway. Oncology 18 6635-6640.

Fernando R \& Wimalasena J 2004 Estradiol abrogates apoptosis in breast cancer cell through inactivation of Bad: ras-dependent non-genomic pathways requiring signaling through ERK and Akt. Molecular Biology of the Cell 7 3266-3284.

Gao Y, Ordas R, Klein JD \& Price SR 2008 Regulation of caspase-3 activity by insulin in skeletal muscle cells involves both PI3-kinase and MEK-1/2. Journal of Applied Physiology 105 1772-1778.

Gatson JW, Maass DL, Simpkins JW, Idris AH, Minei JP \& Wigginton JG 2009 Estrogen treatment following severe burn injury reduces brain inflammation and apoptotic signaling. Journal of Neuroinflammation 630.

Greising SM, Baltgalvis KA, Lowe DA \& Warren GL 2009 Hormone therapy and skeletal muscle strength: a meta-analysis. Journals of Gerontology Series A: Biological Sciences and Medical Sciences 64 1071-1081.

Hu S \& Yang X 2003 Cellular inhibitor of apoptosis 1 and 2 are ubiquitin ligases for the apoptosis inducer Smac/DIABLO. Journal of Biological Chemistry 278 10055-10060.

Jiang X \& Wang X 2000 Cytochrome $c$ promotes caspase-9 activation by inducing nucleotide binding to Apaf-1. Journal of Biological Chemistry 275 31199-31203.

Jiang X \& Wang X 2004 Cytochrome $c$-mediated apoptosis. Annual Review of Biochemistry 73 87-106.

Jiang B, Xiao W, Shi Y, Liu M \& Xiao X 2005 Role of Smac/DIABLO in hydrogen peroxide-induced apoptosis in C2C12 myogenic cells. Free Radical Biology and Medicine 39 658-667.

Kadi F, Karlsson C, Larsson B, Eriksson J, Larval M, Billig H \& Jonsdottir I 2002 The effects of physical activity and estrogen treatment on rat fast and slow skeletal muscles following ovariectomy. Journal of Muscle Research and Cell Motility 23 335-339.

Laemmli UK 1970 Cleavage of structural proteins during the assembly of the head of bacteriophage T4. Nature 227 680-685.

Lazarow A \& Cooperstein SJ 1953 Studies on the enzymatic basis for the Janus Green B staining reaction. Journal of Histochemistry and Cytochemistry 1 234-241.
Liu X, Kim C, Pohl J \& Wang X 1996 Purification and characterization of an interleukin-1 $\beta$-converting enzyme family protease that activates cysteine protease P32 (CPP32). Journal of Biological Chemistry 271 13371-13376.

Lizcano J, Morrice N \& Cohen P 2000 Regulation of Bad by cAMPdependent protein kinase is mediated via phosphorylation of a novel site, Ser155. Biochemical Journal 349 547-557.

Lu A, Frink M, Choudhry M, Hubbard W, Rue L, Bland K \& Chaudry I 2007 Mitochondria play an important role in $17 \beta$-estradiol attenuation of $\mathrm{H}_{2} \mathrm{O}_{2}$-induced rat endothelial cell apoptosis. American Journal of Physiology. Endocrinology and Metabolism 292 585-593.

Manolagas S \& Kousteni S 2001 Perspective: nonreproductive sites of action of reproductive hormones. Endocrinology 142 2200-2204.

Marino M, Acconcia F \& Trentalance A 2003 Biphasic estradiol-induced AKT phosphorylation is modulated by PTEN via MAP kinase in HepG2 cells. Molecular Biology of the Cell 14 2583-2591.

Marzetti E \& Leeuwenburgh C 2006 Skeletal muscle apoptosis, sarcopenia and frailty at old age. Experimental Gerontology 41 1234-1238.

McClung J, Davis J, Wilson M, Goldsmith E \& Carson J 2006 Estrogen status and skeletal muscle recovery from disuse atrophy. Journal of Applied Physiology 100 2012-2023.

Milanesi L, Russo de Boland A \& Boland R 2008 Expression and localization of estrogen receptor $\alpha$ in the $\mathrm{C} 2 \mathrm{C} 12$ murine skeletal muscle cell line. Journal of Cellular Biochemistry 1041 254-273.

Moran A, Nelson S, Landisch R, Warren G \& Lowe D 2007 Estradiol replacement reverses ovariectomy-induced muscle contractile and myosin dysfunction in mature female mice. Journal of Applied Physiology 102 1387-1393.

Pearson G, Robinson F, Beers Gibson T, Xu BE, Karandikar M, Berman K \& Cobb MH 2001 Mitogen-activated protein (MAP) kinase pathways: regulation and physiological functions. Endocrine Reviews 22 153-183.

Persky A, Green P, Stubley L, Howell C, Zaulyanov L, Brazeau G \& Simpkins J 2000 Protective effect of estrogens against oxidative damage to heart and skeletal muscle in vivo and in vitro. Proceedings of the Society for Experimental Biology and Medicine 223 59-66.

Rane MJ \& Klein JB 2009 Regulation of neutrophil apoptosis by modulation of PKB/Akt activation. Frontiers in Bioscience 14 2400-2412.

Razandi M, Pedram A \& Levin ER 2000 Plasma membrane estrogen receptors signal to antiapoptosis in breast cancer. Molecular Endocrinology 14 1434-1447.

Reed JC 1997 Bcl-2 family proteins: regulators of apoptosis and chemoresistance in hematologic malignancies. Seminars in Hematology 34 9-19.

Riedl SJ \& Salvesen GS 2007 The apoptosome: signalling platform of cell death. Nature Reviews. Molecular Cell Biology 8 405-413.

Ronda AC, Buitrago C, Colicheo A, de Boland AR, Roldán E \& Boland R 2007 Activation of MAPKs by $1 \alpha, 25(\mathrm{OH}) 2$-vitamin $\mathrm{D}_{3}$ and $17 \beta$-estradiol in skeletal muscle cells leads to phosphorylation of Elk-1 and CREB transcription factors. Journal of Steroid Biochemistry and Molecular Biology 103 $462-466$.

Saleh A, Srinivasula SM, Balkir L, Robbins PD \& Alnemri ES 2000 Negative regulation of the Apaf-1 apoptosome by Hsp70. Nature Cell Biology 2 476-483.

Sandri M \& Carraro U 1999 Apoptosis of skeletal muscles during development and disease. International Journal of Biochemistry \& Cell Biology 31 1373-1390.

Sandri M, Carraro U, Podhorska-Okolov M, Rizzi C, Arslan P, Monti D \& Franceschi C 1995 Apoptosis, DNA damage and ubiquitin expression in normal and mdx muscle fibers after exercise. FEBS Letters 373 291-295.

Scott A \& Knott M 1974 A cluster analysis method for grouping means in the analysis of variance. Biometrics 30 507-512.

Shimamura A, Ballif BA, Richards SA \& Blenis J 2000 Rsk1 mediates a MEKMAP kinase cell survival signal. Current Biology 10 127-135.

Shiozaki E \& Shi Y 2004 Caspases, IAPs and Smac/DIABLO: mechanisms from structural biology. Trends in Biochemical Sciences 29 486-494.

Simpkins JW, Wang J, Wang X, Perez E, Prokai L \& Dykens JA 2005 Mitochondria play a central role in estrogen-induced neuroprotection. Current Drug Targets. CNS and Neurological Disorders 4 69-83. 
Sitnick M, Foley AM, Brown M \& Spangenburg EE 2006 Ovariectomy prevents the recovery of atrophied gastrocnemius skeletal muscle mass Journal of Applied Physiology 100 286-293.

Steller H 1995 Mechanisms and genes of cellular suicide. Science 267 1445-1449.

Tiidus P 2005 Can oestrogen influence skeletal muscle damage, inflammation, and repair? British Journal of Sports Medicine 39 251-253.

Vasconsuelo A, Milanesi L \& Boland R 2008 17 $\beta$-Estradiol abrogates apoptosis in murine skeletal muscle cells through estrogen receptors: role of the phosphatidylinositol 3-kinase/Akt pathway. Journal of Endocrinology 196 385-397.

Wada T \& Penninger J 2004 Mitogen-activated protein kinases in apoptosis regulation. Oncogene 23 2838-2849.

Warren GL, Lowe DA, Inman CL, Orr OM, Hogan HA, Bloomfield SA \& Armstrong RB 1996 Estradiol effect on anterior crural muscles-tibial bone relationship and susceptibility to injury. Journal of Applied Physiology $\mathbf{8 0}$ 660-665.

Yang E, Zha J, Jockel J, Boise LH, Thompson CB \& Korsmeyer SJ 1995 Bad, a heterodimeric partner for $\mathrm{Bcl}-\mathrm{xl}$ and $\mathrm{Bcl}-2$, displaces $\mathrm{Bax}$ and promotes cell death. Cell 80 285-291.
Yoshida N, Yoshida S, Koishi K, Masuda K \& Nabeshima Y 1998 Cell heterogeneity upon myogenic differentiation: down-regulation of MyoD and Myf-5 generates 'reserve cells'. Journal of Cell Science 111 769-779.

Zha J, Harada H, Yang E, Jockel J \& Korsmeyer SJ 1996 Serine phosphorylation of death agonist BAD in response to survival factor results in binding to 14-3-3 not BCL-X(L). Cell 87 619-628.

Zhu Y, Yang GY, Ahlemeyer B, Pang L, Che XM, Culmsee C, Klumpp S \& Krieglstein J 2002 Transforming growth factor- $\beta 1$ increases bad phosphorylation and protects neurons against damage. Journal of Neuroscience 22 3898-3909.

Received in final form 12 May 2010

Accepted 20 May 2010

Made available online as an Accepted Preprint 20 May 2010 